African Crop Science Journal by African Crop Science Society is licensed under a Creative Commons Attribution 3.0 Uganda License. Based on a work at www.ajol.info/ and www.bioline.org.br/cs DOI: https://dx.doi.org/10.4314/acsj.v28i2.8

\title{
GENE EFFECT AND HERITABILITY OF YIELD AND ITS COMPONENTS IN EGGPLANT
}

\author{
N.T. AFFUL ${ }^{1,2}$, D. NYADANU ${ }^{1}$, R. AKROMAH ${ }^{1}$, H.M. AMOATEY², V. ODURO \\ and C. ANNOR ${ }^{2}$ \\ ${ }^{1}$ Department of Plant and Soil Sciences, Kwame Nkrumah University of Science and Technology, \\ Kumasi, Ghana \\ ${ }^{2}$ Biotechnology Centre, Biotechnology and Nuclear Agriculture Research Institute, Ghana Atomic \\ Energy Commission, Accra, Ghana \\ Corresponding author: enusrat@yahoo.com
}

(Received 14 May 2018; accepted 23 June 2020)

\begin{abstract}
Eggplant (Solanum melongena L.) is one of the most important fruit vegetables in the world, with several nutritional and medicinal benefits. However, little is known about the genetic divergence of yield and its related traits. The objective of this study was to explore gene action and heritability of traits to help direct and strengthen breeding programmes, geared towards improving yield of the crop. Six generations (P1, P2, F1, F2, BC1 and BC2) derived from two crosses (SM001-07 x ST004-03 and SM001 x San005-01) of eggplant accessions, were grown in pots in an open field, using Randomised Complete block Design (RCBD). Estimated data indicated that, the additive-dominance model was adequate to demonstrate the genetic variation and its significance in the inheritance of fruit weight, days to flowering and fruit yield traits. Although non-allelic interactions were found in plant height and number of seeds, additive effect was more pronounced in the genetic control of days to flowering and fruit weight; while dominance effect was more important in the control of plant branching and fruit length. Plant height and fruit yield were influenced by complementary gene action. Furthermore, the study revealed low magnitudes of dominance and environmental variances for most traits showing higher heritability values. In view of the diverse gene actions, with additive, dominant and epistasis, playing significant roles in the control of different traits, backcross, recurrent selection or bi parental could be appropriate for advancing the segregating populations to meet the need of yield improvement in both crosses.
\end{abstract}

Key Words: Additive, dominance, Epistasis, gene action

\section{RÉSUMÉ}

L'aubergine (Solanum melongena L.) est l'un des legumes fruits les plus importants au monde, avec les plusieurs bienfaits nutritionnels et médicinaux. Cependant, on sait peu de choses sur la divergence génétique du rendement et ses traits liés. L'objectif de cette étude était d'explorer l'action des gènes 
et l'héritabilité des traits pour aider à diriger et à renforcer les programmes de sélection visant à améliorer le rendement de la culture. Six générations (P1, P2, F1, F2, BC1 et BC2) dérivées de deux croisements (SM001-07 x ST004-03 et SM001 x San005-01) d'accessions d'aubergines ont été cultivées en pots dans un champ. Les données estimées indiquent que le modèle de dominance additive était adéquat pour démontrer la variation génétique et son importance dans l'hérédité du poids du fruit, des jours de floraison et des traits de rendement des fruits. Bien que des interactions non alléliques aient été trouvées dans la hauteur des plantes et le nombre de graines, l'effet additif était plus prononcé dans le contrôle génétique des jours de floraison et du poids des fruits; tandis que l'effet de dominance était plus important dans le contrôle de la ramification des plantes et de la longueur des fruits. La hauteur des plantes et le rendement des fruits ont été influencés par l'action complémentaire des gènes. De plus, l'étude a révélé de faibles variation de dominance et des variances environnementales pour la plupart des traits présentant des valeurs d'héritabilité plus élevées. Compte tenu des diverses actions des gènes, avec additif, dominant et épistase, jouant un rôle important dans le contrôle des différents traits, le rétrocroisement, la sélection récurrente ou biparentale pourrait être approprié pour faire progresser les populations en ségrégation afin de répondre au besoin d'améliorer le rendement dans les deux croisements.

Mots Clés: Additif, dominance, épistase, action des gènes

\section{INTRODUCTION}

Eggplants (Solanum melongena) are one of the most important fruit vegetables, with world production exceeding 49.4 million tonnes (FAO, 2015). With its great phenotypic variability, eggplant fruits present a good source of dietary fiber and vitamins (vitamins A, B1 and B6), and provides substantial quantities of minerals such as phosphorus, potassium, calcium and magnesium (Raigón et al., 2008; Okmen et al., 2009). Furthermore, they contain high levels of free reducing sugars, anthocyanin, phenols, glycoalkaloids and amide proteins which are linked to their medicinal properties (Mariola et al., 2013; Sabolu et al., 2014). Consequently, they are used as staple food in many tropical and subtropical countries; and are one of the 35 crops judged to be most important for food security (Fowler et al., 2003).

Despite the presence of several valuable attributes described above, fruit yield has been reported to be low in Ghana due to diseases, pest infestation, low soil fertility problems, among others (Kotey et al., 2013). Although an estimated yield of 15 metric tonnes hectare $^{-1}$ year $^{-1}$ has been reported, an average yield of 8 metric tonnes hectare ${ }^{-1}$ year $^{-1}$ is currently being observed (MoFA, 2010). Moreover, low breeding efforts towards eggplant improvement using local varieties/ germplasm has been carried out compared to crops like potato and tomato (Mistry et al., 2016). This implies that most of the available genotypes are selections from indigenous landraces; thus there is a need to develop high yielding varieties/genotypes that would meet both the farmer and consumers requirement.

Yield is the most important agronomic trait in any crop species. It is a complex trait upon which a number of other characters are involved (Adeyanju et al., 2012; Sabolu et al., 2014; Mistry et al., 2016). Eggplant fruit yield is associated with other yield components such as number of fruits and fruit weight, which makes direct selection for yield in a breeding programme difficult (Deshmukh et al., 2014). In this case, selection of genotypes for breeding could be based on genetic variability and correlations for fruit yield and its attributes.

The nature and magnitude of genetic variation present in a population is revealed by genetic analysis of economic quantitative traits. Estimating the type of gene effect and its associations with yield and associated traits, and their interactions in a plant population, is essential to decide the type of breeding method 
to be adopted (Deb and Khaleque, 2009; Arora et al., 2010). Thus, for any breeding programme, information about nature and magnitude of gene action is essential to accelerate the success rate (Shashikumar et al., 2010). This research was, therefore, carried out to explore gene action and heritability of traits to help direct and strengthen breeding programmes geared towards improving the yield of the crop.

\section{MATERIALS AND METHODS}

Plant material. The experiment was conducted at the research field of the Faculty of Agriculture, Kwame Nkrumah University of Science and Technology (KNUST), Ghana (longitude $01^{\circ} 33 \mathrm{~W}$, latitude $06^{\circ} 41 \mathrm{~N}$, annual rainfall of 1100 - 1800 mm, Dystric Cambisol soil of loamy sand and $\mathrm{pH}$ 6.9).

The experiments involved the six basic generations (P1, P2, F1, F2, BC1 and BC2) derived from two crosses, SM001-07 (cultivated) x ST004-03 (wild) and SM00107 x San005-01 (wild). The donor parents (ST004-03 and San005-01) were individually crossed to the recurrent parent (SM001-07) to produce $\mathrm{F}_{1}$ progenies. These progenies were then back crossed to the recurrent parent, to produce $\mathrm{BC}_{1}$ progenies. Thereafter, a selected individual plant was back crossed to the recurrent parent to produce the $\mathrm{BC}_{2}$ progenies. Furthermore, $\mathrm{F}_{1}$ progenies (hybrids) were selfed to obtain $\mathrm{F}_{2}$ population. All the generations were produced during three cropping seasons. These were used for further studies on yield and its contributing traits.

Experimental design. All the ninety six seedlings, comprising all the six generations were grown in pots in an open field, using Randomised Complete block Design. Four plants per generation, with four replicates, were transplanted into pots, such that sixteen plants per generation with a total number of 96 plants from all six generations, were grown. Experimental pots were spaced $80 \mathrm{~cm}$ apart between the different generations.
Data collection. The data recorded included fruit length, fruit breadth, plant height at flowering, number of days to first flowering, number of fruit per plant, number of seeds per fruit, number of primary branches at flowering, fruit weight per plant and fruit yield per plant.

Fruit length was measured from the base of the calyx to the tip of the fruit, while fruit breadth was measured at the broadest part of the fruit. Plant height was obtained by measuring the distance from soil surface to the apical tip of main stem at flowering, using a meter rule. The number of days to first flowering was observed as the number of days from transplanting to the anthesis of first flower.

Number of fruits per plant and number of seeds per fruit were obtained by calculating the means of counted fruits from tagged plants and selected fruits, respectively. Fruit weight of tagged plants was weighed and the mean calculated. The weight of fruits of all harvest multiplied by number of plants per hectare for each of the tagged plant per accession was calculated and the mean as the total yield.

Statistical analysis. All data were subjected to Analysis of Variance (GenStat statistical package, $11^{\text {th }}$ edition) and significant differences among the means were separated by the Tukey's test $(\mathrm{P}<0.05)$. Generation mean analysis was also employed to estimate the gene effect of the various parameters using Plant Breeding Tools, version 1.4. (2014). Variance components (additive, dominance and environment) were estimated as described by Mather and Jinks (1982) using the following equations:

$\mathrm{VA}=4 \mathrm{VF}_{2}-2\left(\mathrm{VBC}_{1}+\mathrm{VBC}_{2}\right) \ldots \ldots . . . \mathrm{Eq} .1$

$\mathrm{VD}=4\left(\mathrm{VB}_{1}+\mathrm{VB}_{2}-\mathrm{VF}_{2}-\mathrm{VE}\right) \ldots \ldots \ldots . \mathrm{Eq} .2$

$\mathrm{VE}=0.25\left(\mathrm{VP}_{1}+\mathrm{VP}_{2}+2 \mathrm{VF}_{1}\right) \ldots \ldots \ldots . . \mathrm{Eq} .3$

Where: 
$\mathrm{VA}=$ additive variance, $\mathrm{VD}=$ Dominance variance and $\mathrm{VE}=$ environmental variance.

Broad-sense (Hbs) and narrow-sense (Hns) heritability were calculated using the following equations by (Mather and Jinks, 1982):

$\left.\mathrm{Hbs}=\left\{\left[\mathrm{VF}_{2}-\left(\mathrm{VP}_{1}+\mathrm{VP}_{2}+2 \mathrm{VF}_{1}\right) / 4\right)\right] / \mathrm{VF}_{2}\right\}$ Eq. 1

$\mathrm{Hns}=\left[\mathrm{VF}_{2}-\left(\mathrm{VBC}_{1}+\mathrm{VBC}_{2}\right) / 2\right] / \mathrm{VF}_{2}$ Eq. 2

\section{RESULTS}

Analysis of variance. Data for analysis of variance for all characters studied in two crosses of eggplant is presented in Table 1. The analysis showed that the mean square due to crosses were significant for all traits. Therefore, generation means for the two crosses could be analysed to estimate the genetic parameters for all investigated traits.

TABLE 1. Analysis of variance for two cross combinations for yield and yield traits of eggplant

\begin{tabular}{|c|c|c|c|c|}
\hline Trait & Cross & $\begin{array}{l}\text { Generation mean } \\
\text { square }(\mathrm{df}=5)\end{array}$ & $\begin{array}{l}\text { Replication mean } \\
\text { square }(\mathrm{df}=3)\end{array}$ & $\begin{array}{c}\text { Error mean } \\
\text { square }(\mathrm{df}=15)\end{array}$ \\
\hline \multirow[t]{2}{*}{ DF } & SM001-07 x ST004-03 & $125.320 * *$ & 1.95 & 4.44 \\
\hline & SM001-07 x San005-01 & $125.319 * *$ & 0.607 & 1.062 \\
\hline \multirow[t]{2}{*}{$\mathrm{PH}$} & SM001-07 x ST004-03 & $15.589 * *$ & 0.096 & 0.240 \\
\hline & SM001-07 x San005-01 & $15.589 * *$ & 0.998 & 0.524 \\
\hline \multirow[t]{2}{*}{$\mathrm{PB}$} & SM001-07 x ST004-03 & $0.944 * *$ & 0.174 & 0.409 \\
\hline & SM001-07 x San005-01 & $0.946^{* *}$ & 1.100 & 0.406 \\
\hline \multirow[t]{2}{*}{$\mathrm{FL}$} & SM001-07 x ST004-03 & $19.224 * *$ & 0.289 & 0.542 \\
\hline & SM001-07 x San005-01 & $19.549 * *$ & 0.5505 & 0.682 \\
\hline \multirow[t]{2}{*}{$\mathrm{FB}$} & SM001-07 x ST004-03 & $18.751 * *$ & 0.352 & 0.512 \\
\hline & SM001-07 x San005-01 & $18.751 * *$ & 0.759 & 0.810 \\
\hline \multirow[t]{2}{*}{$\mathrm{NF} / \mathrm{P}$} & SM001-07 x ST004-03 & $80.900 * *$ & 16.750 & 40.800 \\
\hline & SM001-07 x San005-01 & $8089.665^{* *}$ & 0.045 & 1.204 \\
\hline \multirow[t]{2}{*}{$\mathrm{FY} / \mathrm{P}$} & SM001-07 x ST004-03 & $21759409 * *$ & 165.800 & 408.700 \\
\hline & SM001-07 x San005-01 & $2.176^{* *}$ & 1.377 & 1.356 \\
\hline \multirow[t]{2}{*}{ FW/P } & SM001-07 x ST004-03 & $58085.000 * *$ & 45.800 & 74.000 \\
\hline & SM001-07 x San005-01 & $58115.517 * *$ & 0.727 & 1.311 \\
\hline \multirow[t]{2}{*}{$\mathrm{NS} / \mathrm{F}$} & SM001-07 x ST004-03 & $930159.000 * *$ & 17.25 & 40.55 \\
\hline & SM001-07 x San005-01 & $9.300^{* *}$ & 0.214 & 1.537 \\
\hline
\end{tabular}

$\mathrm{FL}=$ fruit length, $\mathrm{FB}=$ fruit breadth, NF/P = number of fruit per plant, $\mathrm{FW} / \mathrm{P}=$ fruit weight per plant, $\mathrm{DF}$ $=$ number of days to first flower opening $\mathrm{NS} / \mathrm{P}=$ number of seeds per fruit, $\mathrm{PB}=$ number of primary branches at flowering, $\mathrm{PH}=$ plant height at flowering and $\mathrm{FY} / \mathrm{P}=$ fruit yield per plant. $*, * *$ and $\mathrm{ns}=$ significantly different at $\mathrm{P}<0.05,0.01$ and non-significant, respectively 
Yield and yield contributing traits. The mean values, standard errors and coefficients of variation for nine quantitative traits of the six generations with two crosses are presented in Tables 2 and 3. In both crosses, the hybrids $\left(F_{1}\right)$ mean performance was better than the mean value for either parent in all the traits, except for plant height $(32.30 \mathrm{~cm})$ and plant branching (10.11) showing inferior performance to their respective parental generations $\left(\mathrm{P}_{1}\right.$ and $\left.\mathrm{P}_{2}\right)$ with respect to cross SM001-07 x ST004-03 (Table 2). Among the parents, accession SM001-07 recorded the highest fruit yield per plant $\left(7577.93 \mathrm{~kg} \mathrm{ha}^{-1}\right)$ and the lowest was observed in ST004-03 (4686.15 $\left.\mathrm{kg} \mathrm{ha}^{-1}\right)$. Further, parent SM001-07 had the highest number of branches at flowering (10), fruit weight $(408.80 \mathrm{~g})$ and number of seeds per fruit $(1,449)$. Accession ST004-03 presented the highest number for days to flowering (152 days) and number of fruits per plant (232). Besides, accession San005-01 also showed the lowest number of days to first flowering (79 days) and the lowest number of seeds per fruit (46) (Tables 2 and $3)$.
In general, the values of traits for the $F_{1}$ and $\mathrm{F}_{2}$ generations were lower than the corresponding values for $\mathrm{BC}_{1}$ and $\mathrm{BC}_{2}$ generations, except days to first flowering and fruit weight per plant; and fruit yield per plant in crosses SM001-07 x ST004-03 and SM001$07 \times$ San005. Similarly, the $F_{2}$ generation expressed lower mean values than $F_{1}$ in most traits, in both crosses. However the mean values of $\mathrm{F}_{2}$ generation were higher than $\mathrm{F}_{1}$ values for days to flowering, number of fruits per plant (SM001-07 x ST004-03), plant height, fruit weight per plant and number of seeds per plant (SM001-07 x San005-01) (Tables 2 and 3).

With respect to the backcross generations of the two crosses, SM001-07 x ST004-03 recorded higher fruit yield $\left(7854.70 \mathrm{~kg} \mathrm{ha}^{-1}\right)$ compared to cross SM001-07 x San005-01 (1297.75 kg ha ${ }^{-1}$ ) (Tables 2 and 3). Moreover, the value recorded for number of fruits per plant in $\mathrm{BC}_{2}$ generation for both crosses (SM001-07 x ST004-03 and SM001-07 x San005-01) was comparatively higher (47.12 and 30 , respectively) than the value (8.33) observed for the recurrent parent (SM001-07)

TABLE 2. Comparisons of means $( \pm$ SE) for eggplant yield and yield components of cross SM001-07 (S. melongena) x ST004-03 (S. torvum)

\begin{tabular}{lrrrrrrr}
\hline Trait & \multicolumn{7}{c}{ Populations } \\
\cline { 2 - 8 } & \multicolumn{1}{c}{$\mathrm{P}_{1}$} & \multicolumn{1}{c}{$\mathrm{P}_{2}$} & \multicolumn{1}{c}{$\mathrm{F}_{1}$} & \multicolumn{1}{c}{$\mathrm{F}_{2}$} & \multicolumn{1}{c}{$\mathrm{BC}_{1}$} & \multicolumn{1}{c}{$\mathrm{BC}_{2}$} & $\mathrm{CV}$ \\
\hline $\mathrm{DF}$ & $98.30 \pm 0.31$ & $152.30 \pm 0.31$ & $120.00 \pm 2.44$ & $128.00 \pm 1.00$ & $108.00 \pm 1.00$ & $110.20 \pm 1.04$ & 2.10 \\
$\mathrm{PH}$ & $42.49 \pm 0.10$ & $59.62 \pm 0.10$ & $32.30 \pm 0.31$ & $29.50 \pm 0.31$ & $35.03 \pm 0.10$ & $35.92 \pm 0.10$ & 0.10 \\
$\mathrm{~PB}$ & $10.11 \pm 0.10$ & $7.33 \pm 0.10$ & $5.66 \pm 0.10$ & $4.20 \pm 0.31$ & $8.00 \pm 1.00$ & $6.10 \pm 0.31$ & 4.80 \\
FL & $8.36 \pm 0.10$ & $1.58 \pm 0.10$ & $4.93 \pm 0.31$ & $4.03 \pm 0.70$ & $6.70 \pm 0.31$ & $5.30 \pm 0.31$ & 4.40 \\
FB & $8.43 \pm 0.10$ & $1.18 \pm 0.10$ & $3.90 \pm 0.31$ & $3.50 \pm 0.31$ & $3.89 \pm 0.10$ & $4.11 \pm 0.40$ & 2.30 \\
NF/P & $8.33 \pm 0.99$ & $202.89 \pm 10.06$ & $37.1 \mathrm{~b} 2 \pm 1.42$ & $37.7 \pm 0.61$ & $44.22 \pm 1.03$ & $47.1 \mathrm{~b} 2 \pm 1.42$ & 6.70 \\
FY/P & $7577.93 \pm 0.10$ & $4686.15 \pm 0.10$ & $5932.05 \pm 0.01$ & $5932.05 \pm 0.10$ & $7854.70 \pm 0.31$ & $6772.50 \pm 0.31$ & 1.14 \\
FW/P & $408.80 \pm 10.02$ & $252.80 \pm 10.00$ & $305.63 \pm 7.59$ & $286.33 \pm 3.31$ & $313.33 \pm 1.94$ & $309.00 \pm 7.13$ & 2.20 \\
NS/F & $1449.00 \pm 1.00$ & $216.00 \pm 1.00$ & $264.00 \pm 1.00$ & $255.00 \pm 1.00$ & $402.00 \pm 9.94$ & $345.00 \pm 1.00$ & 8.50 \\
\end{tabular}

$\mathrm{FL}=$ fruit length, $\mathrm{FB}$ = fruit breadth, $\mathrm{NF} / \mathrm{P}=$ number of fruit per plant, $\mathrm{FW} / \mathrm{P}=$ fruit weight per plant, $\mathrm{DF}$ $=$ number of days to first flowering, $\mathrm{NS} / \mathrm{P}=$ number of seeds per fruit, $\mathrm{PB}=$ number of primary branches at flowering, $\mathrm{PH}=$ plant height at flowering and $\mathrm{FY} / \mathrm{P}=$ fruit yield 
TABLE 3. Comparisons of means $( \pm \mathrm{SE})$ for eggplant yield and yield components of cross SM001-07 (S. melongena) $\mathrm{x}$ San005-01 (S. anguivi)

\begin{tabular}{lrrrrrrr}
\hline Trait & \multicolumn{7}{c}{ Populations } \\
\cline { 2 - 8 } & \multicolumn{1}{c}{$\mathrm{P}_{1}$} & \multicolumn{1}{c}{$\mathrm{P}_{2}$} & \multicolumn{1}{c}{$\mathrm{F}_{1}$} & \multicolumn{1}{c}{$\mathrm{F}_{2}$} & $\mathrm{BC}_{1}$ & $\mathrm{BC}_{2}$ & $\mathrm{CV}$ \\
\hline $\mathrm{DF}$ & $98.30 \pm 0.31$ & $79.30 \pm 0.31$ & $86.67 \pm 1.00$ & $84.06 \pm 0.99$ & $84.72 \pm 1.00$ & $83.38 \pm 3.29$ & 5.20 \\
$\mathrm{PH}$ & $42.49 \pm 0.10$ & $49.44 \pm 0.10$ & $45.02 \pm 0.10$ & $46.11 \pm 0.10$ & $45.34 \pm 0.76$ & $46.71 \pm 0.10$ & 0.40 \\
$\mathrm{~PB}$ & $10.11 \pm 0.10$ & $8.67 \pm 0.10$ & $9.98 \pm 0.10$ & $8.99 \pm 0.10$ & $9.22 \pm 1.00$ & $9.78 \pm 1.24$ & 4.40 \\
$\mathrm{FL}$ & $8.36 \pm 0.10$ & $1.16 \pm 0.10$ & $7.1 \mathrm{~b} 3 \pm 0.10$ & $5.22 \pm 0.10$ & $6.81 \pm 0.99$ & $6.58 \pm 0.99$ & 9.20 \\
FB & $8.43 \pm 0.10$ & $0.90 \pm 0.31$ & $5.98 \pm 0.10$ & $4.88 \pm 0.10$ & $6.51 \pm 1.00$ & $5.31 \pm 1.00$ & 9.60 \\
NF/P & $8.33 \pm 0.99$ & $148.11 \pm 10.00$ & $25 \pm 1.00$ & $21.00 \pm 1.00$ & $27.00 \pm 1.00$ & $30 \pm 1.00$ & 4.30 \\
FY/P & $7577.93 \pm 0.10$ & $595.04 \pm 0.10$ & $956.98 \pm 0.10$ & $916.93 \pm 3.16$ & $1297.75 \pm 3.62$ & $631.08 \pm 4.02$ & 9.40 \\
FW/P & $408.80 \pm 10.02$ & $32.10 \pm 3.15$ & $332.40 \pm 9.99$ & $404.70 \pm 10.00$ & $334.96 \pm 2.35$ & $302.00 \pm 9.97$ & 4.5 \\
NS/F & $1449.00 \pm 1.00$ & $46.00 \pm 1.00$ & $77.66 \pm 1.23$ & $86.00 \pm 1.00$ & $100.00 \pm 1.00$ & $122.73 \pm 10.00$ & 12.90 \\
\hline
\end{tabular}

$\mathrm{FL}=$ fruit length, $\mathrm{FB}=$ fruit breadth, $\mathrm{NF} / \mathrm{P}=$ number of fruit per plant, $\mathrm{FW} / \mathrm{P}=$ fruit weight per plant, $\mathrm{DF}$ $=$ number of days to first flowering, $\mathrm{NS} / \mathrm{P}=$ number of seeds per fruit, $\mathrm{PB}=$ number of primary branches at flowering, $\mathrm{PH}=$ plant height at flowering and $\mathrm{FY} / \mathrm{P}=$ fruit yield

and $F_{1}$ generation (37.12 and 25, respectively) (Tables 2 and 3).

The number of seeds per fruit was substantially reduced from 1,449 in the recurrent parent to 345 and 122 in $\mathrm{BC}_{2}$ generation for crosses SM001-07 x ST00403 and SM001-07 x San005-01, respectively. Similarly, the number of days to flowering decreased from 98 (recurrent parent) to 83 days $\left(\mathrm{BC}_{2}\right)$ in the case of cross SM001-07 $\mathrm{x}$ San005-01 (Table 2).

Gene action for yield and its components. The results obtained for gene action of the various traits are shown in Tables 4 and 5 . The expected mean of the two crosses (SM001-07 x ST004-03 and SM001-07 x San005-01) were positive and significant $(\mathrm{P}<0.05)$ among generations, for all studied traits except for number of days to first flowering and number of seeds per fruit in cross SM001-07 x ST004-03 (Table 4). The additive, dominance and epistatic gene effects varied between the two crosses for the different traits. Additive gene effect (a) was observed to be higher than dominance values (d) in both crosses (SM001-07 x ST004-03 and SM001-07 x San005-01). However, fruit length (both crosses), days to flowering, fruit yield per plant (SM001-07 x ST004-03) and plant branching were governed by dominance gene effect. Further, among the interaction gene effects, the dominance $\mathrm{x}$ dominance (dd) interaction effect was larger than either of the additive $x$ additive (aa) and additive $x$ dominance (ad) effects in both crosses (Tables 4 and 5).

For number of days to first flowering, the additive effect was negative and significant in cross SM001-07 x ST004-03 (Table 4). However, positive and significant additive gene effect was noted in SM001-07 x San005-01 cross (Tables 4 and 5). Similarly, the interaction effect of additive $\mathrm{x}$ dominance was negative and significant in SM001-07 x San005-01, but a positive and non-significant interaction was recorded for SM001-07 x ST004-03. Besides, the additive value (5.50) was higher than the dominance value (5.24) in cross SM001-07 x San005-01; while dominance value (-106.35) was greater than the additive value $(-27)$ in cross SM001-07 x ST004-03 (Tables 4 and $5)$. 
TABLE 4. Estimate of gene effects on eggplant yield and yield traits of the cross SM001-07 x ST004-03 (S. melongena x S. torvum)

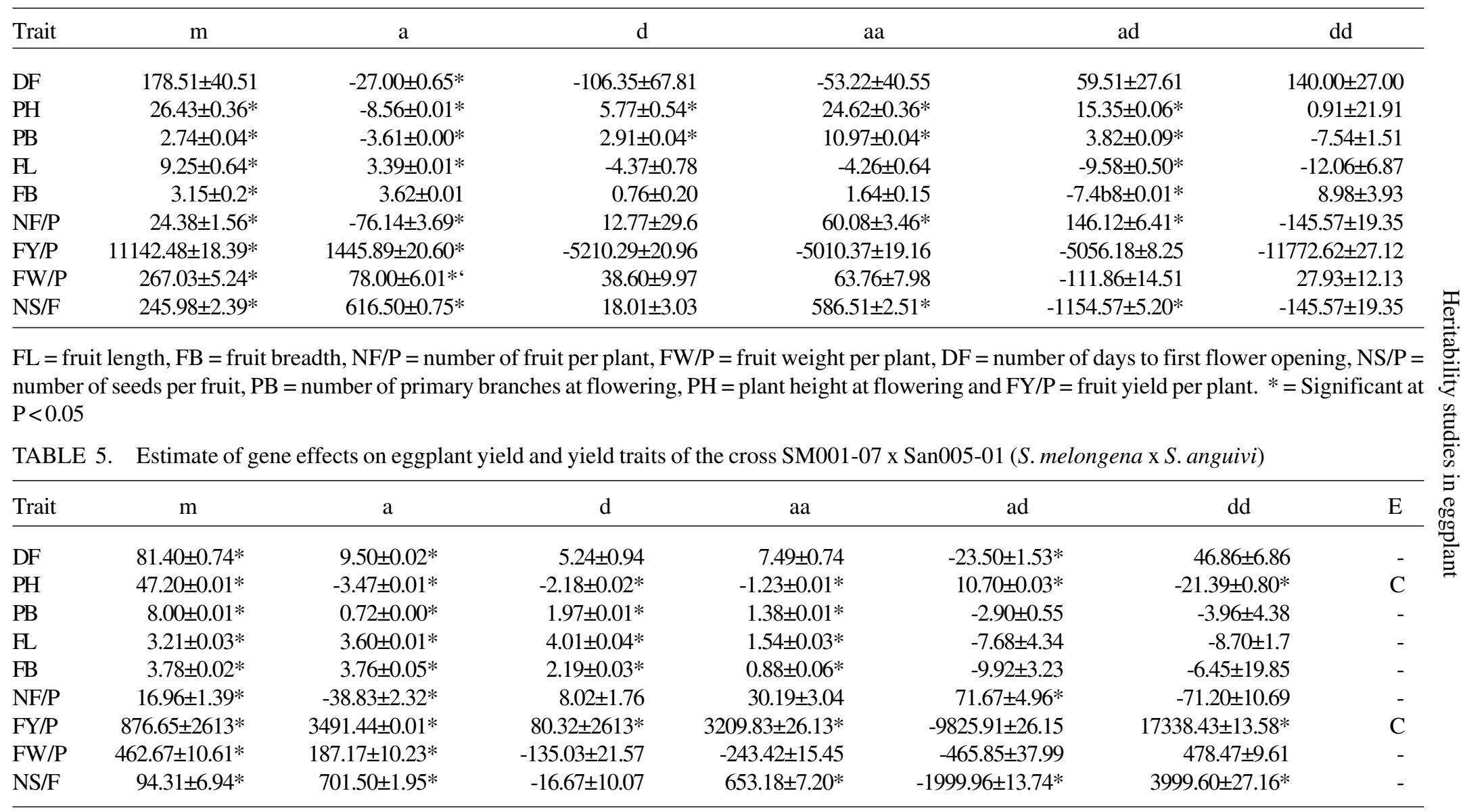

$\mathrm{FL}=$ fruit length, $\mathrm{FB}=$ fruit breadth, NF/P = number of fruit per plant, $\mathrm{FW} / \mathrm{P}=$ fruit weight per plant, $\mathrm{DF}=$ number of days to first flower opening, $\mathrm{NS} / \mathrm{P}=$ number of seeds per fruit, $\mathrm{PB}=$ number of primary branches at flowering, $\mathrm{PH}=$ plant height at flowering and $\mathrm{FY} / \mathrm{P}=$ fruit $\mathrm{yield}$. $\mathrm{E}=$ type of epistasis, $\mathrm{D}=$ duplicate, $\mathrm{C}=$ complementary, $=$ no epistasis. $*$ Significant at $\mathrm{P}<0.05$ 
Plant height trait for both crosses exhibited significant major gene effects together with gene interactions effects, except for dominance $\mathrm{x}$ dominance gene effect in cross SM001-07 x ST004-03 (Tables 4 and 5). The additive gene effects in both crosses were also negative and significant; and additive values were higher than dominance values in both crosses. Cross SM001-07 x San005-01 showed the complementary type of epistasis.

A significant additive, dominance, additive $\mathrm{x}$ additive and additive $\mathrm{x}$ dominance gene effects were observed for plant branching in cross SM001-07 x ST004-03; while cross SM001-07 x San005-01 was significant for additive, dominance and additive $\mathrm{x}$ additive gene effects (Tables 4 and 5). The values for additive $\mathrm{x}$ additive gene effect in both crosses (10.97 and 1.38) were higher than the values obtained for only additive gene effect (-3.61 and 0.72). However, in cross SM001-07 x ST004-03, additive effect (-3.61) was greater than dominance effect (2.91); while dominance gene effect (1.97) was higher than additive effect (0.72) in the case of cross SM001-07 x San005-01.

With regard to fruit length, the cross SM001-07 x ST004-03 showed a positive and significant additive effect, but gene effect due to additive $\mathrm{x}$ dominance interaction was significant and negative. Whereas cross SM001-07 x San005-01 revealed a positive and significant additive, dominance and additive $\mathrm{x}$ additive interaction effects (Tables 4 and 5). However, in both crosses (SM001-07 x ST004-03 and SM001-07 x San005-01), the values for dominance gene effect was higher $(-4.37 ; 4.10)$ than that of additive values $(3.39$, $3.60)$. Further, the additive $x$ dominance interaction effect was greater than the major gene effects and the additive $\mathrm{x}$ additive gene interaction in both crosses.

The additive, dominance and additive $\mathrm{x}$ additive gene effects were positive and significant for fruit breadth trait in cross SM001-07 x San005-01 (Table 4). However, in cross SM001-07 x ST004-03, only the additive $\mathrm{x}$ dominance gene interaction effect was found significant. Nonetheless, in both crosses, the additive gene effect was higher than the dominance effect. Similarly, the additive $\mathrm{x}$ dominance gene effect was higher than additive, dominance and additive $\mathrm{x}$ additive gene effects put together for the same trait (Tables 4 and 5).

As for number of fruits per plant, both crosses showed negative and significant gene effects for the additive component; while the interaction effect for additive $\mathrm{x}$ dominant component was observed to be positive and significant (Tables 4 and 5). In addition, the additive and additive $\mathrm{x}$ dominance gene interaction values were higher than the dominance values. However, the additive $\mathrm{x}$ additive gene effect was positive and significant only in cross SM001-07 x ST004-03.

The results obtained for fruit yield per plant, showed the significance of additive gene effect for this trait in SM001-07 x ST004-03 cross; whereas in cross SM001-07 x San005-01, additive, dominance, additive $\mathrm{x}$ additive and dominance $\mathrm{x}$ dominance interaction were found to be significant (Tables 4 and 5). Additive gene effects were also positive and significant in both crosses. Moreover, the additive gene effect values $(1445.89,3491.44)$ were greater than the values obtained for dominance gene effect $(5210.29,80.32)$ in crosses SM001-07 x ST004-03 and SM001-07 x San005-01, respectively. The complementary type of epistasis was observed in cross SM001-07 x San005-01.

In the case of fruit weight per plant, both crosses (SM001-07 x ST004-03 and SM00107 x San005-01) showed positive and significant additive gene effects. Besides, the additive gene effect was found to be greater than dominance gene effects in both crosses (Tables 4 and 5).

The number of seeds per fruit was significant and positive for additive and additive $x$ additive interaction gene effect, but a negative and significant additive $\mathrm{x}$ dominance interaction effects was recorded for cross 
SM001-07 x ST004-03. However, for cross SM001-07 x San005-01, additive, additive $\mathrm{x}$ additive, additive $\mathrm{x}$ dominance and dominance $x$ dominance effects were important in the inheritance of this trait (Tables 4 and 5).

The results obtained for fruit yield per plant showed the significance of additive gene effect for this trait in SM001-07 x ST004-03 cross; whereas in the cross SM001-07 x San00501 , additive, dominance, additive $\mathrm{x}$ additive and dominance $\mathrm{x}$ dominance interaction were found significant (Tables 4 and 5). Additive gene effects were also observed to be positive and significant in both crosses. Moreover, the additive gene effect values $(1445.89,3491.44)$ were greater than the values obtained for dominance gene effect $(5210.29,80.32)$ in crosses SM001-07 x ST004-03 and SM001$07 \mathrm{x}$ San005-01, respectively. The complementary type of epistasis was observed in cross SM001-07 x San005-01.

In the case of fruit weight per plant, both crosses (SM001-07 x ST004-03 and SM001$07 \times$ San005-01) showed positive and significant additive gene effects. Besides, the additive gene effect was found to be greater than dominance gene effects in both crosses (Tables 4 and 5).
The 'number of seeds per fruit' was significant and positive for additive and additive $x$ additive interaction gene effect, but a negative and significant additive $\mathrm{x}$ dominance interaction effects was recorded for SM00107 x ST004-03 (Tables 4 and 5). However, for cross SM001-07 x San005-01, additive, additive $\mathrm{x}$ additive, additive $\mathrm{x}$ dominance and dominance $x$ dominance effects were important in the inheritance of this trait. Also, the additive $\mathrm{x}$ dominance gene effect in SM001-07 x ST004-03 cross had a greater gene effect compared to that of additive or dominant effect. In general, additive effect values were greater than the dominance gene effect in both crosses (Tables 4 and 5).

\section{Estimates of variance components and} heritability for yield and yield components. The genetic variance components and heritability studies for all yield related traits are shown in Tables 6 and 7, for crosses SM00107 x ST004-03 and SM001-07 x San005-01, respectively. Although variations were observed in the estimated values of additive and dominance variances between the two crosses under study, the additive variance was found to be higher than dominance variance.

TABLE 6. Estimates of variance components and heritability of cross SM001-07 x ST004-03

\begin{tabular}{lrrrrrrr}
\hline Trait & VA & VD & VE & VP & VG & Hbs & Hns \\
\hline DF & 4.73 & -1.69 & 0.17 & 3.21 & 3.04 & 94.80 & 15.18 \\
PH & -11.61 & 3.05 & 1.22 & -7.34 & -8.56 & 16.66 & 85.22 \\
PB & 3.26 & -1.48 & 0.65 & 2.43 & 1.78 & 73.27 & 78.71 \\
FL & 4.31 & -1.77 & 0.49 & 3.03 & 2.54 & 83.89 & 13.07 \\
FB & 6.31 & -3.34 & 1.24 & 4.21 & 2.97 & 70.55 & 26.62 \\
NF/P & 7.10 & -3.87 & 1.70 & 4.93 & 3.23 & 65.53 & 35.03 \\
FY/P & -1.51 & 0.17 & 0.99 & -0.35 & -1.34 & 37.97 & 53.30 \\
FW/P & -5.75 & 1.73 & 0.50 & -3.52 & -4.02 & 11.43 & 20.26 \\
NS/F & 12.44 & -5.65 & 2.87 & 9.66 & 6.79 & 70.26 & 12.02 \\
\hline
\end{tabular}

$\mathrm{VA}=$ additive variance; $\mathrm{VD}=$ dominance variance; $\mathrm{VE}=$ environmental variance, $\mathrm{VP}$ - phenotypic variance, $\mathrm{VG}=$ genotypic variance; $\mathrm{Hbs}$ = broadsense heritability; Hns = narrow sense heritability, FL $=$ fruit length, $\mathrm{FB}=$ fruit breadth, $\mathrm{NF} / \mathrm{P}=$ number of fruit per plant, $\mathrm{FW} / \mathrm{P}=$ fruit weight per plant, $\mathrm{DF}=$ number of days to first flower opening, $\mathrm{NS} / \mathrm{F}=$ number of seeds per fruit, $\mathrm{PB}=$ number of primary branches at flowering, $\mathrm{PH}=$ plant height at flowering and $\mathrm{FY} / \mathrm{P}=$ fruit yield 
TABLE 7. Estimates of variance components and heritability of cross SM001-07 x San005-01

\begin{tabular}{llllllll}
\hline Trait & VA & VD & VE & VP & VG & Hbs & Hns \\
\hline DF & 2.22 & -1.22 & 0.81 & 1.81 & 1.00 & 55.51 & 40.33 \\
PH & 2.90 & -1.64 & 1.07 & 2.33 & 1.26 & 53.95 & 67.75 \\
PB & 4.02 & -1.62 & 0.62 & 3.02 & 2.40 & 79.32 & 12.14 \\
FL & 1.15 & -1.05 & 0.82 & 0.92 & 0.10 & 10.69 & 10.64 \\
FB & 2.84 & -1.73 & 1.20 & 2.31 & 1.11 & 48.17 & 65.51 \\
NF/P & 9.92 & -3.97 & 1.44 & 7.39 & 5.95 & 80.45 & 73.27 \\
FY/P & 4.00 & -2.00 & 1.01 & 3.01 & 2.00 & 66.44 & 12.04 \\
FW/P & 6.18 & -2.51 & 0.76 & 4.43 & 3.67 & 82.90 & 27.42 \\
NS/F & 8.87 & -4.73 & 3.09 & 7.23 & 4.14 & 57.27 & 64.05 \\
\hline
\end{tabular}

$\mathrm{VA}=$ additive variance $\mathrm{VD}=$ dominance variance $\mathrm{VE}=$ environmental variance, $\mathrm{VP}=$ phenotypic variance, $\mathrm{VG}$ = genotypic variance; $\mathrm{Hbs}$ = broadsense heritability; Hns - narrow sense heritability, FL = fruit length, $\mathrm{FB}$-fruit breadth, $\mathrm{NF} / \mathrm{P}=$ number of fruit per plant, $\mathrm{FW} / \mathrm{P}=$ fruit weight per plant, $\mathrm{DF}=$ number of days to first flower opening, NS/P = number of seeds per fruit, $\mathrm{PB}=$ number of primary branches at flowering, $\mathrm{PH}=$ plant height at flowering and $\mathrm{FY} / \mathrm{P}=$ fruit yield

The additive variance estimates for days to flowering, plant branching, fruit length, fruit breadth, number of fruit per plant and number of seeds per fruit were positive; while their dominance variance estimates were negative. The number of seeds per fruit had the highest environmental variance with values of 2.87 and 3.09 in crosses SM001-07 x ST004-03 and SM001-07 x San005-01, respectively (Tables 6 and 7 ). The lowest environmental variance was recorded in days to first flowering (0.17) in cross SM001-07 x ST00403 , while plant branching $(0.62)$ had the lowest in cross SM001-07 x San005-01 for the same component (Tables 6 and 7 ).

Heritability estimates varied considerably between the two crosses (Tables 6 and 7). In cross SM001-07 x ST004-03, broad sense heritability ranged from $11.43(\mathrm{FW} / \mathrm{P})$ to $94.80 \%$ (DF), and from 10.69 (FL) to $82.90 \%$ (FW/P) in cross SM001-07 x San005-01. For narrow sense heritability, number of seed per fruit had the lowest estimated value (12.02\%); while the highest was recorded in plant height (85.22\%) in cross SM001-07 x ST004-03. The range in cross SM001-07 x San005-01 was 10.64 (FL) to $73.27 \%$ (NF/P) (Tables 6 and
7). In addition, plant branching and number of fruits per plant showed high (above 70\%) broad and narrow sense heritability in both crosses.

\section{DISCUSSION}

Analysis of variance. The differential performance of genotypes in segregating populations has often been ascribed to the presence of genetic variation (Adeyanju et al., 2012). The highly significant differences observed among generations for days to flowering, plant height, branching, fruit length, fruit breadth, number of fruits per plant, fruit yield per plant and fruit weight per plant indicate the presence of genetic variability and the possibility of selection of genotypes for specific trait(s) in the eggplant population. Similar results have been reported for yield related quantitative traits by Mistry et al. (2016) in eggplant.

Mean comparison. The higher mean performance of progenies $\left(\mathrm{F}_{1}, \mathrm{~F}_{2}, \mathrm{BC}_{1}\right.$ and $\mathrm{BC}_{2}$ generations) in both crosses, over the parents $\left(\mathrm{P}_{1}\right.$ or $\left.\mathrm{P}_{2}\right)$ for most traits, revealed the 
involvement of dominance gene action. Therefore, for improvement of these traits, recurrent or backcross selection methods, followed by selection in a later generation, could produce better results. This is in congruence with studies conducted by Mistry et al. (2016) and Sabolu et al. (2014), who reported on the preponderance of dominance gene action for fruit yield and quality in eggplant. However, the higher mean value recorded for number of fruits per plant in $\mathrm{BC}_{2}$ generation (both crosses) compared to the average value observed for the recurrent parent (SM001-07, $\mathrm{P}_{1}$ ) and $\mathrm{F}_{1}$ indicated accumulation genes for high number of fruits in backcross generations.

Similar result was reported by Mistry et al. (2016) for number of fruits per plant in eggplants. Number of seeds per fruit (both crosses) and number of days to flowering was significantly reduced in $\mathrm{BC}_{2}$ generation compared to the recurrent parent (SM001-07). This reduction is desirable as it shows the accumulation of genes for earliness and low number of seeds in this backcross generation. Higher values of days to flowering, number of fruits per plant, plant height, fruit weight per plant and number of seeds per fruit recorded for $F_{2}$ generation, compared to $F_{1}$ generation, indicate the absence of inbreeding depression. All other traits presented higher $F_{1}$ values compared to $F_{2}$ values which suggest the presence of inbreeding depression for those traits.

Variance components and heritability estimates. The estimate of variance components and heritability varied among the two crosses for the different traits measured (Tables 6 and 7). The additive variance estimates for days to flowering, plant branching, fruit length, fruit breadth, number of fruit per plant and number of seeds per fruit were positive; while their dominance variance estimates were negative. Further, additive variance was higher than dominance variance in all traits measured. The genetic improvement of these traits can, thus be achieved by using backcross, single seed descent or pedigree selection breeding methods. Moreover, the lower magnitudes of environmental variance recorded for all traits indicate that these traits are under genotypic control. Similar results were reported by Akpan et al. (2016) in eggplant.

Comparison between broad and narrow sense heritability showed equal significance of additive and non-additive effects (above $70 \%$ ) in the control of number of fruit per plant (SM001-07 x San005-01) and plant branching (SM001-07 x ST004-03), which was evidenced by the low magnitude of dominant and environmental variances (Tables 6 and 7). High broad sense heritability estimate (above $60 \%$ ) was recorded for fruit width, days to flower opening, number of fruit per plant, number of seed per fruit (SM001-07 x ST00403), plant branching, fruit yield per plant and fruit weight per plant (SM001-07 x San00501). This indicates the importance of both additive and non-additive gene effects in control of these traits. This is in consonance with the observations made by Sharaf Uddin et al. (2015) when they worked on some economic traits in eggplant. Narrow sense heritability was also high for plant height (both crosses), fruit breadth and number of seeds per fruit (SM001-07 x San005-01). The higher values of these traits suggest that they are controlled largely by genes acting in an additive fashion.

\section{CONCLUSION}

Progeny mean performances in all four generations $\left(\mathrm{F}_{1}, \mathrm{~F}_{2}, \mathrm{BC}_{1}\right.$ and $\left.\mathrm{BC}_{2}\right)$ for days to flowering and number of seeds per fruit were lower than the mean values of one of the respective parents $\left(\mathrm{P}_{1}\right.$ or $\left.\mathrm{P}_{2}\right)$. However, higher mean values were observed for number of fruits per plant. The inheritance of yield and yield traits, using generation mean analysis, revealed all three types of gene actions; additive, dominant and epistasis. However, the 
preponderance of additive and dominance gene effects were higher for fruit weight, plant branching and fruit length, respectively. Meantime additive $\mathrm{x}$ additive genes controlled the inheritance of plant height and plant branching (SM001-07 x San005-01) while additive $\mathrm{x}$ dominance was prominent for number of fruits per plant (both crosses), days to flowering (SM001-07 x San005-01), fruit length, fruit breadth and number of seeds per fruit (SM001-07 x San005-01). Dominance x dominance gene interaction effect was more pronounced in plant height and plant branching (SM001-07 x San005-01). Therefore selection procedures such as backcross and recurrent selection methods could be adopted for improvement of these traits.

\section{ACKNOWLEDGEMENT}

Financial assistance from Government of Ghana as bursary for the first author is gratefully acknowledged.

\section{REFERENCES}

Adeyanju, A.O., Ishiyaku, M.F., Echekwu, C.A. and Olarewaju, J.D. 2012. Generation mean analysis of dual purpose traits in cowpea (Vigna unguiculata [L.] walp.). African Journal of Biotechnology 11(46):10473-10483.

Akpan, N.M., Ogbonna, P.E., Onyia, V.N., Okechukwu, E.C. and Atugwu, I.A. 2016. Variability studies on ten genotypes of eggplant for growth and yield performance in South Eastern Nigeria. Journal of Animal and Plant Science 26(4):10341041.

Arora, D., Jindal, S.K., and Ghai, T.R. 2010. Quantitative inheritance for fruit traits in inters varietal crosses of okra (Abelmoschus esculentus L. Moench). Electronic Journal of Plant Breeding 1:1434-1442.

Deb, A.C. and Khaleque, M.A. 2009. Nature of gene action of some quantitative traits in chickpea (Cicer arietinum L.). World
Journal of Agricultural Sciences 5(3):361368.

Deshmukh, S.B., Sawant, S.N., Narkhede, G.W. and Dod, V.N. 2014. Gene action studies in Brinjal (Solanum melongena). Middle-East Journal of Scientific Research 21(11): 2177-2181.

FAO. 2015. FAOSTAT production databases. Food and Agriculture Organization, Rome. $<$ http://www.faostat3.fao.org >. Assessed: August, 2015.

Fowler, C., Moore, G. and Hawtin, G.C. 2003. The International Treaty on plant genetic resources for food and agriculture: A primer for the future harvest centres of the CGIAR. International Plant Genetic Resources Institute, Rome, Italy.

Kotey, D.A., Osekre, E.A., Badger, N.G. and Ahiats, E.N. 2013. Evaluation of eggplant, Solanum spp. germplasm against field insect pests' infestation at Bunso in the Eastern Region of Ghana. Journal of Biology, Agriculture and Healthcare 3(18): 28-37.

Mariola, P., Isabel, A., Santiago, V., Maria, H., Pietro, G., Francisco, J.H. and Jaime, P. 2013. Breeding for chlorogenic acid content in eggplant: Interest and prospects. Notulae Botanicae Horti Agrobotanici 41(1):26-35.

Mather, K. and Jinks, J.L. 1982. Biometrical Genetics: The study of continuous variation. Chapman and Hall Inc., London.

Mistry, C., Keshubhai, B.K., Sabolu, S. and Kumar, S. 2016. Heritability and gene effects for yield related quantitative traits in eggplant. Annals of Agricultural Sciences 61(2):237-246.

MoFA. 2010. Agriculture in Ghana: Facts and figures. Policy planning, monitoring and evaluation directorate. Ministry of Food and Agriculture. Accra, Ghana.

Okmen B, Sigva, H.O., Mutlu, S., Doganlar, S., Yemenicioglu, A. and Frary, A. 2009. Total antioxidant activity and total phenolic contents in different Turkish eggplant (Solanum melongena L.) cultivars. 
International Journal of Food Properties 12:616-624.

Raigon, M.D., Prohens, J., Munoz-Falcon, J. and Nuez, F. 2008. Comparison of eggplant landraces and commercial varieties for fruit content of phenolics, minerals, dry matter and protein. Journal of Food Composition and Analysis 21:370-376.

Sabolu, S., Kathiria, K.B., Mistry, C.R. and Kumar, S. 2014. Generation mean analysis of fruit quality traits in eggplant (Solanum melongena L.). Australian Journal of Crop Science 8(2):243-250.
Sharaf Uddin, M., Rahman, M.M., Hossain, M.M. and Khaleque Mian, M.K. 2015. Combining ability of yield and yield components in eggplant (Solanum melongena L.) during summer. Universal Journal of Plant Science 3(4):59-66.

Shashikumar, K.T., Pitchaimuthu, M. and Rawal, R.D. 2010 Generation mean analysis of resistance to downy mildew in adult muskmelon plants. Euphytica 173:121-127. 